\title{
AUDIT ON PLATELET TRANSFUSION AT MGM BLOOD BANK: A RETROSPECTIVE STUDY
}

\author{
Seema Gupta1, Shweta Biyani², Lakshita Varshney³ \\ ${ }^{1}$ Associate Professor and Blood Bank Incharge, Department of Immunohematology and Blood Transfusion, MGM Medical College, \\ Navi Mumbai. \\ 2Assistant Professor, Department of Immunohematology and Blood Transfusion, MGM Medical College, Navi Mumbai. \\ 3 Post Graduate Student, Department of Immunohematology and Blood Transfusion, MGM Medical College, Navi Mumbai.
}

\begin{tabular}{l}
\hline ABSTRACT \\
AIMS AND BACKGROUND \\
Platelet transfusion is an important treatment modality for prevention and treatment of bleeding. Indiscriminate use and non- \\
compliance to platelet transfusion have been found despite having various guidelines and recommendations. This study is aimed at \\
assessing the preparation, utilization and discard of platelets in our hospital.
\end{tabular}

\section{MATERIAL AND METHODS}

We conducted a retrospective study in the Department of Immunohematology and Blood Transfusion at MGM Medical College and Hospital, Kamothe, Navi Mumbai, for a period of 4 months from 1st July to 31st October 2015, wherein appropriate utilization, major users, $\mathrm{ABO}$ group specific or non-group specific platelet transfusions and expiry rates were analysed.

\section{RESULT}

A total of 1806 whole blood units were collected, of which 1708 (94.5\%) units were separated into components. Of these, 1067 platelets were prepared; 213 platelet requisitions were received for 162 patients at our blood bank. Of these, 185 platelet requisitions were evaluable in which $128(69.1 \%)$ had appropriate utilization pattern conforming to the BCSH guidelines. Out of 992 RDP transfusions, 684 (68.9\%) were ABO group specific, while remaining were given across the barrier. Major users were dengue patients followed by malaria, which together accounted for $61.49 \%$. Expiry rate was found to be $7.02 \%$.

\section{CONCLUSION}

Regular audits, application of transfusion guidelines and clinician training programmes are necessary for rational and judicious use of platelet.

\section{KEYWORDS}

Platelet Transfusion, Audit, Blood Bank, Appropriate.

HOW TO CITE THIS ARTICLE: Gupta S, Biyani S, Varshney L. Audit on platelet transfusion at MGM blood bank: a retrospective study. J. Evolution Med. Dent. Sci. 2016;5(57):3956-3959, DOI: 10.14260/jemds/2016/903

\section{INTRODUCTION}

Platelets play a key role in maintaining haemostasis. They are amongst the most valuable and expensive commodities in transfusion medicine.(1) Platelet transfusion is an important therapeutic modality, which can be life-saving in certain circumstances and its demand is on rise. However, the decision to transfuse platelets should be taken carefully, as it exposes the patient to various risks and can lead to deprivation of this precious product to actually needy patients.

In 1910, it was Duke who first recognized that increase in platelet counts after the transfusion of whole blood led to increased haemostasis.(2) However, routine transfusion of platelets, independent of fresh whole-blood transfusion, was not feasible until 1960s. This delay was because of the technical inability to isolate and preserve platelets for transfusions. With advances in the collection and storage of platelets, routine platelet transfusions for thrombocytopenic patients became possible.(3)

Financial or Other, Competing Interest: None.

Submission 10-06-2016, Peer Review 04-07-2016,

Acceptance 11-07-2016, Published 18-07-2016.

Corresponding Author:

Dr. Seema Gupta,

\#502, West End,

Sector-19A, Nerul, Navi Mumbai,

Maharashtra.

E-mail: seemaagupta@gmail.com

DOI: $10.14260 /$ jemds $/ 2016 / 903$
Allogeneic platelet transfusions are generally used as a treatment modality to treat or to prevent bleeding in thrombocytopenic patients and platelet dysfunction. The degree of thrombocytopenia correlates with the risk of bleeding.(4) and the investigators have defined an appropriate platelet transfusion trigger based on the absolute platelet count. An optimal trigger should be sufficiently high to prevent bleeding, yet sufficiently low to avoid needless transfusions and their associated risks, which include the transmission of infection, allergic reactions, platelet refractoriness, transfusion-related acute lung injury and venous thromboembolism.(5)

Despite having various guidelines for platelet transfusion that are aimed at increasing their clinical effectiveness and reducing the side effects, non-compliance is frequently seen.(6)

Platelet transfusion audit is an important tool to reduce inappropriate transfusion in patients, while continuously improving practice guidelines, encouraging consultation with prescribers and identifying areas for further improvement.(6) The present study was undertaken to review the platelet transfusion practices at our health care centre.

\section{MATERIALS AND METHODS}

This is a retrospective study conducted in the Department of Immunohematology and Blood Transfusion at MGM Medical College and Hospital, Kamothe, Navi Mumbai, over a period of 4 months from $1^{\text {st }}$ July to $31^{\text {st }}$ October 2015. 
This study is aimed at describing the pattern of platelet utilization in our hospital.

Patient's data was collected from the requisition forms with respect to age, gender, diagnosis, indication of transfusion, platelet count, no. of units requested and issued, transfusion episodes, ABO and Rh (D) group or non-group specificity. An assessment was also made regarding appropriateness of transfusion and expiry rate.

Appropriateness of transfusion was assessed as per BCSH guidelines given in Box 1.

\section{BOX 1 - BCSH Guidelines for Platelet Transfusion}

\begin{tabular}{|c|l|}
\hline & \multicolumn{1}{|c|}{ Prophylactic } \\
\hline 1 & $\begin{array}{l}\text { To prevent spontaneous bleeding (e.g. Dengue): when } \\
\text { platelet count }<10000 / \text { uL }\end{array}$ \\
\hline 2 & $\begin{array}{l}\text { Presence of risk factors like sepsis (fever) or } \\
\text { haemostatic abnormalities, transfuse when platelet } \\
\text { count }<20000 / \text { L }\end{array}$ \\
\hline 3 & $\begin{array}{l}\text { To prevent bleeding associated with invasive } \\
\text { procedure raise to }>50000 \text { (e.g. lumbar } \\
\text { puncture/liver biopsy) and }>1 \text { lakh/uL in case of } \\
\text { ophthalmic or neurosurgery }\end{array}$ \\
\hline 4 & $\begin{array}{l}\text { Critical care/surgery. Massive blood transfusion with } \\
1.5-2 \text { times blood volume. Aim to maintain platelet } \\
\text { count }>50000 / \text { uL }\end{array}$ \\
\hline 5 & $\begin{array}{l}\text { Platelets dysfunction: following CABG anti-platelets } \\
\text { drugs (clopidogrel) }\end{array}$ \\
\hline 6 & $\begin{array}{l}\text { Acute DIC - in the presence of bleeding and severe } \\
\text { thrombocytopenia }\end{array}$ \\
\hline 7 & $\begin{array}{l}\text { Inherited platelet dysfunction, e.g. Glanzmann } \\
\text { thrombasthenia with bleeding or as prophylaxis } \\
\text { before surgery }\end{array}$ \\
\hline & \multicolumn{1}{c|}{ Therapeutic } \\
\hline & $\begin{array}{l}\text { Bleeds from oral cavity, mucous membrane or any } \\
\text { other site with platelet dysfunction irrespective of the } \\
\text { platelet count }\end{array}$ \\
\hline
\end{tabular}

Platelets concentrate from whole blood can be prepared by PRP method or buffy-coat method and by plateletpheresis using cell separator. Platelets issued in our hospital were RDP concentrate prepared by PRP method of fresh whole blood; light spin is given first at $1500 \mathrm{rpm}$ for $18 \mathrm{mins}(350 \mathrm{~mL}$ bags) or $1700 \mathrm{rpm}$ for $15 \mathrm{mins}$ ( $450 \mathrm{~mL}$ bags) and then after separation of the PRP into satellite bags, a hard spin is given at $2500 \mathrm{rpm}$ for $10 \mathrm{mins}$. The supernatant is collected in plasma bag as FFP and platelets are re-suspended in 50-70 $\mathrm{mL}$ of plasma.

\section{RESULTS}

During the 4-month study period, a total of 1806 [1801 $(99.72 \%)$ voluntary and $05(0.28 \%)$ related donations] blood collection were made; 1708 (94.57\%) units were separated into 4477 components and 1067 platelets were prepared. Of these, 992 platelets were utilized and 75 were discarded with expiry rate of $7.02 \%$.

During this period, 213 platelet requisitions were received for 162 patients, of which 108 (66.6\%) were males and $54(33.3 \%)$ were females. Mean age of the patients who received transfusion was 39 years ranging from neonates to 72 years.

Out of 213 requisitions, 185 (86.85\%) were evaluable and rest were excluded because of insufficient data available to determine the utilization pattern. Of these, 128 (69.1\%) had appropriate utilization conforming to BCSH guideline.

The most common indication for platelet transfusion was dengue followed by malaria, which together accounted for 61.49\%. The indications are summarized in Table 1.

\begin{tabular}{|c|c|c|}
\hline Indications & No. & $\mathbf{N \%}$ \\
\hline Dengue & 85 & $39.90 \%$ \\
\hline Malaria & 59 & $27.69 \%$ \\
\hline Pancytopenia & 10 & $4.69 \%$ \\
\hline Sepsis & 9 & $4.22 \%$ \\
\hline RDS & 4 & $1.87 \%$ \\
\hline DIC & 4 & $1.87 \%$ \\
\hline Others* & 42 & $19.71 \%$ \\
\hline Total & $\mathbf{2 1 3}$ & $\mathbf{1 0 0 . 0 \%}$ \\
\hline Table 1: Indication for Platelets Transfusion \\
\hline
\end{tabular}

*Others include hepatorenal syndrome, pancreatitis, intestinal perforation, pneumonitis, hemoperitonium, CKD, etc.

The pattern of Platelet utilization according to various specialities has been shown in Table 2, in which Medicine Department accounted for $48.3 \%$ of platelets being utilized in our hospital.

\begin{tabular}{|c|c|c|}
\hline Department & Platelet Issued & N\% \\
\hline Medicine & 480 & 48.38 \\
\hline ICU & 278 & 28.02 \\
\hline Surgery (Incl. CVTS) & 32 & 3.22 \\
\hline OBGY & 12 & 1.20 \\
\hline $\begin{array}{c}\text { Paediatrics (Incl. PICU, } \\
\text { NICU) }\end{array}$ & 43 & 4.33 \\
\hline Orthopaedics & 2 & 0.20 \\
\hline EMS & 72 & 7.25 \\
\hline Others & 73 & 7.28 \\
\hline Total & $\mathbf{9 9 2}$ & $\mathbf{1 0 0 . 0}$ \\
\hline \multicolumn{2}{|c|}{ Table 2: Utilization Pattern According to Speciality } \\
\hline
\end{tabular}

Out of 992 RDP transfusions, 684 (68.9\%) were ABO and $\mathrm{Rh}$ (D) group specific, while remaining were given across the ABO barrier to patients (Table 3). Average RDP transfusion per episode came out to be $4.65 \%$.

\begin{tabular}{|c|c|c|}
\hline $\begin{array}{c}\text { Blood } \\
\text { Groups }\end{array}$ & $\begin{array}{c}\text { Group Specific } \\
\text { Transfusions }\end{array}$ & $\begin{array}{c}\text { Across Barriers } \\
\text { Transfusions }\end{array}$ \\
\hline A & 201 & 57 \\
\hline $\mathrm{B}$ & 265 & 78 \\
\hline $\mathrm{AB}$ & 29 & 49 \\
\hline $\mathrm{O}$ & 195 & 118 \\
\hline Total & $\mathbf{6 9 0}$ & $\mathbf{3 0 2}$ \\
\hline Total \% & $\mathbf{6 9 . 5 6 \%}$ & $\mathbf{3 0 . 4 4 \%}$ \\
\hline \multicolumn{2}{|c|}{ Table 3: ABO Group Specific and Across } \\
Barrier Transfusion
\end{tabular}

\section{DISCUSSION}

During the last two decades all over the world, platelet utilization has increased more than the use of any other blood component. $(7,8,9)$ With advancement in blood bank practice, there is constant availability of the platelets. Due to easy availability, indiscriminate use has been found to be rampant and despite sufficient guidelines and recommendations available, platelets usage remains the most misused component. This inappropriate use of blood and its components have a significant impact on the patients and the hospital staff in the form of health care cost,(10,11) wastage of 
resources, depriving more needy patients and transmission of infection with unnecessary allergic reaction leading to high mortality and morbidity in the patients.(12)

In our study, most of the platelets were utilized for patients of infectious aetiology. This can be attributed to the fact that our institute is located near the Mumbai-Pune Expressway catering to the nearby rural areas. Hence, infectious diseases and trauma cases are dealt more frequently. In other studies, hemato-oncology discipline was the major user for platelet concentrate. Since our institute does not support oncology setup, we found that Medicine Department was the major user with most common indications being dengue followed by malaria.

We found that out of 992 RDP transfusions, 690 (69.55\%) were ABO group specific while 302 (30.44\%) were transfused across the ABO barrier (Table 3). Although, it is always best to transfuse $\mathrm{ABO}$ and $\mathrm{Rh}$ group specific platelets in situations where they are not available, transfusing RDP across the ABO barrier is well accepted widely. At our institute, 0 blood group $(39.07 \%)$ was the most frequent group to be transfused across the ABO barrier followed by B (25.82\%), as 0 and B blood groups are the most prevalent blood groups in our region ( $40 \%$ and $25 \%$ respectively).(13) In study of K Saluja et al, group $\mathrm{B}(38 \%)$ platelet transfusion was most frequent when transfusing across the $\mathrm{ABO}$ blood group barrier.

In different studies, the percentage of inappropriate platelet use ranges from $12 \%$ in $\mathrm{K}$ Saluja et al to $44.1 \%$ in Mozes et al (Table 4). In our study, it was found to be $30.9 \%$. This high percentage of inappropriate use may be due to multiple reasons like lack of awareness regarding transfusion guidelines, fear of endangering patient's life if not transfused, emergency situations wherein lab results are not available and decision to transfuse is to be made on clinical grounds.

In an attempt to reduce inappropriate transfusion and creating awareness amongst clinicians, transfusions guidelines are printed in reverse of requisitions forms; training programmes are arranged for interns and first year resident doctors. An elective posting for interns in blood bank have been arranged, so that they can be trained for good blood bank transfusion practice.

In this audit we encountered platelet expiry rate of 7.1\%, which is very close to the expiry rate of $5.8-6.4 \%$ quoted by Qprobe study, while evaluating 1639 hospitals throughout U.S. This could be attributed to the fact that the study was performed during high demand period for platelets, so most of the platelets prepared could be utilized. Besides this, our institute uses bags with shelf life of 5 days for platelets and hospital policy allows us to issue platelets across the $\mathrm{ABO}$ barrier.

\begin{tabular}{|c|c|c|}
\hline $\begin{array}{c}\text { Various } \\
\text { Studies }\end{array}$ & $\begin{array}{c}\text { Year of } \\
\text { Study }\end{array}$ & $\begin{array}{c}\text { Inappropriate use of } \\
\text { Platelets (\%) }\end{array}$ \\
\hline Vishwanathan et al(14) & 1999 & $30.39 \%$ \\
\hline K Saluja et al(6) & 2007 & $12 \%$ \\
\hline Jamal R et al(1) & 1998 & $18.5 \%$ \\
\hline Hui et al(15) & 2005 & $12 \%$ \\
\hline Poonam et al(16) & 2014 & $36 \%$ \\
\hline Mozes et al(17) & 1989 & $44.1 \%$ \\
\hline Our study & 2016 & $30.9 \%$ \\
\hline \multicolumn{2}{|c|}{ Table 4: Inappropriate Use of Platelet } \\
Comparison of Various Studies \\
\hline
\end{tabular}

\section{CONCLUSION}

Regular audit helps us to assess the current platelet transfusion practices and to identify areas of deficiencies, so that appropriate remedial measures can be taken. It will be a fruitful exercise if greater awareness can be created by educating the clinicians, especially at the resident and intern level. This can be done by conducting regular workshops, seminars, lectures and presentations for educating the clinicians and residents regarding transfusion trigger and filling of the feedback forms completely.(16)

\section{ACKNOWLEDGEMENT}

We would like to thank MGM Medical College and Hospital for allowing us to conduct this audit and Blood Bank staff for cooperating in collecting the data.

\section{REFERENCES}

1. Jamal R, Hoe TS, Ong LC, et al. A clinical audit on the practice of platelet transfusions at a tertiary paediatric referral centre. Malaysian J Pathol 1998;20(1):35-40.

2. Duke WW. The relation of blood platelets to hemorrhagic disease: description of a method for determining the bleeding time and coagulation time and report of the three cases of hemorrhagic disease relieved by transfusion. JAMA 1910;55(14):1185-92.

3. Hanson SR, Slichter SJ. Platelet kinetics in patients with bone marrow hypoplasia: evidence for a fixed platelet requirement. Blood 1985;66(5):1105-9.

4. Gaydos LA, Freireich EJ, Mantel N. The quantitative relation between platelet count and hemorrhage in patients with acute leukemia. N Engl J Med 1962;266:905-9.

5. Heal JM, Blumberg N. Optimizing platelet transfusion therapy. Blood Rev 2004;18(3):149-65.

6. Saluja K, Thakral B, Marwaha N, et al. Assessment and utilisation of this precious resource from a tertiary care hospital. Asian Journal of Transfusion Science 2007;1(1):8-11.

7. British committee for standards in haematology, blood transfusion task force. Guidelines for the use of platelet transfusions. Br J Haematol 2003;122(1):10-23.

8. Schiffer CA, Anderson KC, Bennett CL, et al. Platelet transfusion for patients with cancer: clinical practice guidelines of the American society of clinical oncology. J Clin Oncol 2001;19(5):1519-38.

9. Wallace EL, Churchill WH, Surgenor DM, et al. Collection and transfusion of blood and blood components in the United States, 1994. Transfusion 1998;38(7):625-36.

10. Cheng G, Wong HF, Chan A, et al. The effects of a selfeducating blood component request form and enforcements of transfusion guidelines on FFP and platelet usage. Queen Mary hospital, Hong Kong. BCSH. Clin Lab Haematol 1996;18(2):83-7.

11. Marconi M, Almini D, Pizzi MN, et al. Quality assurance of clinical transfusion practice by implementation of the privilege of blood prescription and computerized prospective audit of blood requests. Transfus Med 1996;6(1):11-9.

12. Venkatachalapathy TS, Das S. A review of blood transfusion requests in RL Jalappa hospital and research centre for blood and blood components. J Blood Disord Transfus 2012;3(2):119. 
13. Harmening D. The ABO blood group system. Modern blood banking \& transfusion practices. $6^{\text {th }}$ edn. New Delhi, Jaypee publishers, Table 6-7, 2013:pp 122.

14. Vishwanathan C, Jain R, Kamath M. Blood utilization review in a tertiary care hospital. Ind J Hemat Blood Transf 1999;17(2):26-31.

15. Hui CH, Williams I, Davis K. Clinical audit of the use of fresh-frozen plasma and platelets in a tertiary teaching hospital and the impact of a new transfusion request form. Int Med J 2005;35(5):283-8.
16. Poonam S, Rajni B, Singh BH, et al. Audit of random donor platelets utilization in a tertiary care centre of north India. Journal of Advance Researches in Biological Sciences 2014;6(3):204-8.

17. Mozes B, Epstein M, Bassat BI, et al. Evaluation of the appropriateness of blood and blood product transfusion using preset criteria. Transfusion 1989;29(6):473-6. 